\title{
Absolute tree-ring dates for the Late Bronze Age eruptions of Aniakchak and Thera in light of a proposed revision of ice-core chronologies
}

Jonny McAneney ${ }^{1, *} \&$ Mike Baillie ${ }^{2}$

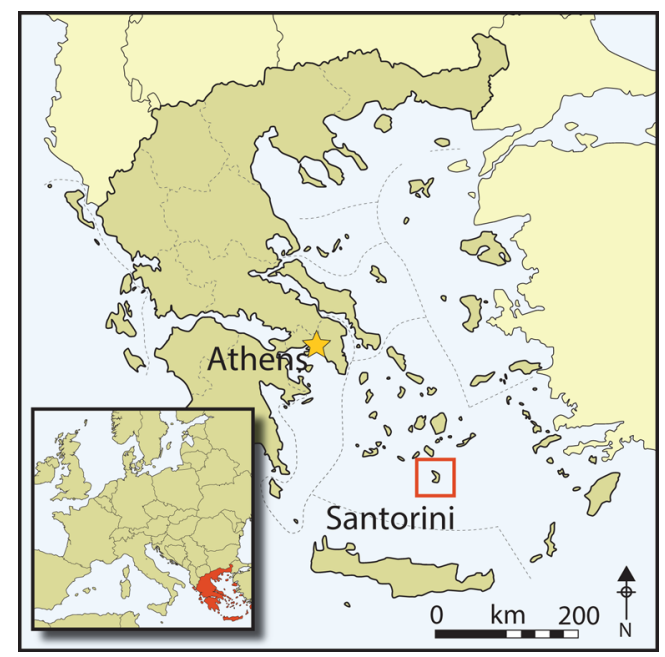

By linking ice-core volcanic horizons with precisely dated frost damage in bristlecone pines, the authors have revised the dating of the principal Greenland ice-core chronologies back to c. 2000 BC. This revision has implications for establishing an absolute calendar date for the Bronze Age eruption of Thera. Three volcanic horizons (1653, 1627 and $1610 \mathrm{BC}$ ) are now coincident with the seventeenth-century $B C$ radiocarbon dating of Thera, but none of these horizons is likely to result from the Theran eruption. In particular, a volcanic event at c. $1627 \mathrm{BC}$-a date associated with Thera for over 30 years - can now probably be attributed to the Aniakchak II volcano in Alaska.

Keywords: Santorini, Thera, chronology, radiocarbon dating, ice cores, tree rings

\section{Introduction}

The precise dating of the Bronze Age eruption of Thera, Santorini, is key to understanding Aegean, Egyptian and Near Eastern chronologies. Material from the eruption provides a clear datum on archaeological sites, which, if dated, would be fundamental to synchronisation between these Late Bronze Age Mediterranean civilisations. The dating of the eruption, however, is controversial, and scholars fall into two 'camps': a 'young' chronology camp, which dates the eruption to the sixteenth or early fifteenth century BC, and an 'old' chronology camp, which believes the eruption occurred in the seventeenth century BC; for a detailed review of the debate, see Manning (2014).

1 Independent researcher, 8 Silverstream Gardens, Bangor BT20 3LS, UK

2 School of Natural and Built Environment, Queen's University Belfast, Belfast BT7 1NN, UK

* Author for correspondence (Email: jonnymca@hotmail.com) 
The 'young' chronology is favoured by many archaeologists, and is based on interpretations of archaeological evidence and suspicions about the integrity of radiocarbon samples (e.g. Bietak (2003, 2014) and Cherubini et al. (2013, 2014)). Conversely, the 'old' chronology is favoured by those who accept the radiocarbon dates of archaeological samples and buried wood from Santorini-evidence that suggests that Thera erupted in the second half of the seventeenth century cal BC (Bronk Ramsey et al. 2004; Friedrich et al. 2006; Manning et al. 2006, 2014). Attempts to use remote proxies-namely, evidence in ice-core and tree-ring records-have suggested various seventeenth-century BC dates for Thera. All, however, are based upon three key assumptions: that the eruption was unusually large, chronologically isolated and climatically effective (i.e. it temporarily altered the climate on a hemispheric or global scale in the years immediately after the eruption). These assumptions permitted LaMarche and Hirschboeck (1984), for example, to propose that their 1627 BC bristlecone pine frost-ring might have been caused by Thera on the basis that, at that time in 1984, there were no other known eruptions during the seventeenth-century BC—previously published ice-core records reported no volcanic acid layers during the seventeenth century $\mathrm{BC}$, but radiocarbon evidence was suggesting a seventeenth century BC date for Thera. Similarly, Hammer et al. (1987) suggested that an acid layer in the Greenland Dye3 ice core dated to $1645 \pm 20 \mathrm{BC}(1641 \pm 5 \mathrm{BC}$ in the GICC05 timescale; Vinther et al. 2006) - the largest in centuries - was most probably due to the exceptional and isolated eruption of Thera. Finally, Baillie and Munro (1988) proposed that the Irish oak narrowest ring event, starting in 1628 $\mathrm{BC}$, might, through coincidence with the LaMarche and Hirschboeck frost-ring date, relate to the eruption of Thera.

Thus, the ice dates 1645/1641 BC and tree-ring dates 1628/1627 BC became associated with the Thera debate. The only other suggestion of a near-exact date is based on anomalous growth observed in Anatolian trees from Porsuk- 'downwind' from Thera-dating to 1650 $+4 /-7$ cal BC (Manning et al. 2001; Pearson et al. 2009) i.e. a single year between $1654-1643 \mathrm{cal}$ BC. Subsequent radiocarbon dating of the Porsuk site chronology, however, has determined that the anomaly occurred around 20 years earlier than originally determined, thus ruling out the relevance of the date as being too old (Manning et al. 2016).

In this article, we extend our previous work (Baillie \& McAneney 2015) to obtain a new revised ice-core chronology dating back to $c$. $2000 \mathrm{BC}$, allowing us to examine the true volcanic history of the seventeenth century BC. We demonstrate that the $1641 \mathrm{BC}$ ice date and $1627 \mathrm{BC}$ tree-ring date are, in fact, signatures of the same volcanic event-probably attributable to Aniakchak II in south-west Alaska—and examine the implications of this new icecore chronology for the precise dating of the eruption of Thera.

\section{The developing debate}

LaMarche and Hirschboeck (1984) knew that Thera was a large eruption and that radiocarbon evidence suggested a possible seventeenth century BC date. They also knew that bristlecone pine frost rings occurred following explosive volcanic eruptions in the second millennium $\mathrm{AD}$, and also in the year after the historical $44 \mathrm{BC}$ dust veil. Although Mount Etna is mentioned historically in association with this $44 \mathrm{BC}$ event, the magnitude of the climatic dislocation in the years 44-40 BC strongly suggests that other eruptions were the (C) Antiquity Publications Ltd, 2019 
driving force. LaMarche and Hirschboeck (1984) proposed that their solitary seventeenthcentury BC frost ring - in $1627 \mathrm{BC}$-might be due to the environmental effects of Thera erupting, either in that year, or possibly one or two years earlier. While this suggestion of $1627 \mathrm{BC}$ was reasonable at the time, a subsequent bristlecone frost ring was dated to 1653 BC (Salzer \& Hughes 2007). Had that evidence been available in 1984, LaMarche and Hirschboeck may have presented their argument differently.

Similarly, assuming that Thera was a large, isolated eruption, Hammer et al. (1987) assigned a large acid signal in the Dye 3 ice core at $1645 \pm 20 \mathrm{BC}$ to sulphur output from Thera. This date was later refined to $1641 \pm 5 \mathrm{BC}$ in the Greenland Ice Core Chronology 2005 (GICC05) timescale (Vinther et al. 2006). While the original Dye3 date range bracketed the LaMarche and Hirschboeck (1984) date, Hammer et al. (1987) and, subsequently, Clausen et al. (1997) and Vinther et al. (2006) refused to consider that the acid signal might be associated with the $1627 \mathrm{BC}$ frost-ring date. This refusal was based on misplaced confidence in the dating accuracy of their ice cores. Baillie $(2008,2010)$ and Baillie and McAneney (2015), however, questioned the accuracy of the GICC05 timescale, suggesting that it was too old by approximately seven years prior to $\mathrm{AD} 1000$. This seven-year offset was confirmed by Sigl et al. (2015). A brief overview of the debate is presented in the online supplementary material (OSM).

\section{Implications of the ice-core dating error for the Thera debate}

The now-accepted ice-dating mistake has clear significance for ice-derived discussions relating to the Thera debate. If GICC05 ice dates in the first millennium AD must be moved forward by seven years, then all earlier dates, such as $1641 \pm 5 \mathrm{BC}$, must also be moved forward by at least seven years. Put bluntly, there never was a 1640s BC acid signal in Greenland ice.

Volcanic acid cannot be attributed to specific volcanoes without definitive tephra analysis from glass shards recovered from the ice layers. We also know from Baillie and McAneney (2015) and Sigl et al. (2015) that intervals between frost rings in bristlecone pines—and nearidentical intervals between acid layers in ice cores-allow sense to be made of the global volcanic story between $430 \mathrm{BC}$ and $\mathrm{AD} 1000$. Following this logic, here we use a list of tiedates between volcanic acid layers in two independent Greenland ice cores - that of the European Greenland Ice Core Project using the GICC05 timescale (GICC05 GRIP) and the American Greenland Ice Sheet Project (GISP2) (Zielinski et al. 1994; Seierstad et al. 2014) — to extend the list of ice-acid intervals. We then compare these intervals with the bristlecone pine frost-ring record of Salzer and Hughes (2007) to ascertain the chronological offset between ice-core and tree-ring dates, back to $c .2000$ BC (Table 1). We only consider frost rings and not years of growth minima within the bristlecone pine chronology; although poor growth can be caused by climatic dislocation due to volcanic forcing, it could also be caused by other non-volcanic factors, such as local environmental conditions. Frost rings, in contrast, are caused only by extreme cold. It is important to emphasise that not all frost rings are caused by large explosive volcanic eruptions, and also that not all such eruptions cause frost rings. As is evident from Baillie and McAneney (2015) and from Table 1, however, frost rings do appear to be excellent indicators of the environmental effects of volcanic activity. 
Table 1. Interval analysis between tie dates of volcanic acid in two ice cores (GRIP using the GICC05 timescale and GISP2) (Zielinski et al. 1994; Seierstad et al. 2014) and the dates of bristlecone pine frost rings (Salzer \& Hughes 2007). Negative dates denote the year BC (e.g. $-43=43 \mathrm{BC})$. Values in parentheses denote the interval between two successive dates. Dates marked with a ' $D$ ' in the GISP2 core denote damaged ice where we expect an acid signal matching the GRIP acid signal would have occurred. The chronological offset between the acid signals in each core and bristlecone pine frost rings is also listed, with negative/positive numbers indicating that the ice is too old/young with regard to the tree dates.

\begin{tabular}{|c|c|c|c|c|c|}
\hline GRIP GICC05 & GISP2 & GISP2 sulphate (ppb) & Frost ring & GRIP-frost ring & GISP2-frost ring \\
\hline $\begin{array}{l}1169 \\
(63)\end{array}$ & $\begin{array}{c}1165.45 \\
(61.7)\end{array}$ & 105.2 & $\begin{array}{c}1171 \\
(62)\end{array}$ & -2 & -5.55 \\
\hline $\begin{array}{l}1106 \\
(81)\end{array}$ & $\begin{array}{c}1103.75 \\
(77.05)\end{array}$ & 132.9 & $\begin{array}{l}1109 \\
(80)\end{array}$ & -3 & -5.25 \\
\hline $\begin{array}{l}1025 \\
(350)\end{array}$ & $\begin{array}{c}1026.7 \\
(335)\end{array}$ & 77.5 & $\begin{array}{l}1029 \\
(348)\end{array}$ & -4 & -2.3 \\
\hline $\begin{array}{l}675 \\
(54)\end{array}$ & $\begin{array}{c}691.7 \\
(51.85)\end{array}$ & 117.7 & $\begin{array}{l}681 \\
(54)\end{array}$ & -6 & +10.7 \\
\hline $\begin{array}{l}621 \\
(87)\end{array}$ & 639.85 & 178.4 & $\begin{array}{l}627 \\
(86)\end{array}$ & -6 & +12.85 \\
\hline $\begin{array}{l}534 \\
(5)\end{array}$ & $\begin{array}{c}\mathrm{D} \\
(110)\end{array}$ & - & $\begin{array}{l}541 \\
(5)\end{array}$ & -7 & - \\
\hline $\begin{array}{l}529 \\
(13)\end{array}$ & $\mathrm{D}$ & - & $\begin{array}{l}536 \\
(14)\end{array}$ & -7 & - \\
\hline $\begin{array}{l}516 \\
(54)\end{array}$ & $\begin{array}{l}529.85 \\
(57.15)\end{array}$ & 51.6 & $\begin{array}{l}522 \\
(53)\end{array}$ & -6 & +7.85 \\
\hline $\begin{array}{l}462 \\
(203)\end{array}$ & $\begin{array}{c}472.7 \\
(207.6)\end{array}$ & 62.0 & $\begin{array}{c}469 \\
(201)\end{array}$ & -7 & +3.7 \\
\hline $\begin{array}{l}259 \\
(310)\end{array}$ & $\begin{array}{c}265.1 \\
(317.9)\end{array}$ & 82.7 & $\begin{array}{c}268 \\
(310)\end{array}$ & -9 & -2.9 \\
\hline $\begin{array}{l}-52 \\
(200)\end{array}$ & $\begin{array}{l}-53.8 \\
(199.6)\end{array}$ & 327.3 & $\begin{array}{l}-43 \\
(201)\end{array}$ & -9 & -10.8 \\
\hline $\begin{array}{l}-252 \\
(110)\end{array}$ & $\begin{array}{l}-253.4 \\
(111.2)\end{array}$ & 83.6 & $\begin{array}{l}-244 \\
(111)\end{array}$ & -8 & -9.4 \\
\hline $\begin{array}{l}-362 \\
(130)\end{array}$ & $\begin{array}{c}-364.6 \\
(125.15)\end{array}$ & 93.0 & $\begin{array}{l}-355 \\
(125)\end{array}$ & -7 & -9.6 \\
\hline $\begin{array}{l}-492 \\
(91)\end{array}$ & $\begin{array}{c}-489.75 \\
(94.6)\end{array}$ & 62.6 & $\begin{array}{c}-480 \\
(90)\end{array}$ & -12 & -9.75 \\
\hline $\begin{array}{l}-583 \\
(138)\end{array}$ & $\begin{array}{l}-584.35 \\
(143.05)\end{array}$ & 165.9 & $\begin{array}{l}-570 \\
(141)\end{array}$ & -13 & -14.35 \\
\hline $\begin{array}{l}-721 \\
(586)\end{array}$ & $\begin{array}{l}-727.4 \\
(599.8)\end{array}$ & 64.3 & $\begin{array}{l}-711 \\
(586)\end{array}$ & -10 & -16.4 \\
\hline $\begin{array}{l}-1307 \\
(124)\end{array}$ & $\begin{array}{l}-1327.2 \\
(126.75)\end{array}$ & 78.7 & $\begin{array}{c}-1297 \\
(122)\end{array}$ & -10 & -30.2 \\
\hline $\begin{array}{l}-1431 \\
(210)\end{array}$ & $\begin{array}{c}-1453.95 \\
(214.9)\end{array}$ & 197.2 & $\begin{array}{c}-1419 \\
(208)\end{array}$ & -12 & -34.95 \\
\hline
\end{tabular}

(C) Antiquity Publications Ltd, 2019 
Table 1. Continued.

\begin{tabular}{lccccc}
\hline GRIP GICC05 & GISP2 & GISP2 sulphate $(\mathrm{ppb})$ & Frost ring & GRIP-frost ring & GISP2-frost ring \\
\hline-1641 & -1668.85 & 109.5 & -1627 & -14 & -41.85 \\
$(26)$ & $(26.4)$ & & $(26)$ & & -42.25 \\
-1667 & -1695.25 & 245.94 & -1653 & -14 & - \\
$(382)$ & & & $(383)$ & & - \\
-2049 & $\mathrm{D}$ & - & -2036 & -13 & - \\
\hline
\end{tabular}

Table 1 shows the gradual increase in dating offset in the European GICC05 ice record, and the much more dramatic increase in offset in the American GISP2 ice core. It is now obvious why the chemistry of the GRIP and GISP2 ice-core chronologies appeared not to replicate before the second millennium $\mathrm{AD}$; while the two cores record the same events, the different chronological offsets within each core made these events appear separate and unrelated. We can supply further information adding to the robustness of the list. The icecore acid signals at ice date 583 (GRIP) and 584.35 (GISP2) 'BC' (frost ring $570 \mathrm{BC}$ ) are preceded in both the GRIP and GISP2 cores by a significant ammonium signal, making this a firm tie point for synchronising the two cores. Moreover, the 1431 ' $\mathrm{BC}$ ' acid signal in GRIP spans five years, as does the 1452.95 'BC' acid signal in GISP2. Note here, and below, that we use the term ' $\mathrm{BC}$ ' to denote pseudo-calendar dates derived from ice-core chronologies and $\mathrm{BC}$ to denote real absolute calendar dates, such as those derived from tree-ring chronologies. Furthermore, Adolphi and Muscheler (2016) compared concentrations of the cosmogenic isotope beryllium 10 in Greenland ice cores with the IntCal13 radiocarbon calibration curve. They found that, by the seventeenth century BC, the seven-year offset in GICC05 had grown to around $20 \pm 5$ years, matching a similar observation by Southon (2002). Those findings support our observation that the chronological offset between tree rings and ice cores using the GICC05 timescale increases in magnitude with increasing ice-core depth.

With these new revised ice-acid dates for the seventeenth century BC, rapid progress can be made in understanding the volcanic history of that century. Salzer and Hughes (2007) record only two frost-ring events in the century-namely 1653 and 1627 BC—26 years apart. Searching for ice-core acid signals spaced 26 years apart, we find that only two large acid spikes in GISP2-1695.25 and 1668.85 'BC' mid points, and 1667 and 1641 'BC' in the GRIP GICC05 timescale-conform (Table 2). As the tree-ring dates are fixed in time, we can apply the dating correction implied in Table 1 to all the ice-core dates (see Figure 1).

Assuming this re-dating of the ice cores is correct, then the original propositions of LaMarche and Hirschboeck (1984) and Hammer et al. (1987) are seen to be unfounded: firstly, the $1627 \mathrm{BC}$ frost ring is not unique within the seventeenth century; and, secondly, the allegedly exceptional $1645 / 1644$ 'BC' acid signal identified by Hammer et al. (1987) is now seen to represent only one of several significant acid signals in the seventeenth century BC. 
Table 2. Tree-ring dates for frost-rings and the ice-core dating estimates before and after correction.

\begin{tabular}{|c|c|c|c|c|}
\hline Frost rings & GRIP GICC05 & GISP2 (mid-point) & GISP2 Peak $\mathrm{SO}_{4}(\mathrm{ppb})$ & Revised date \\
\hline- & $1685^{\prime} \mathrm{BC}$ ' & $1715.5^{\prime} \mathrm{BC}$ ' & 58.61 & $1671 \mathrm{BC}$ \\
\hline $1653 \mathrm{BC}$ & 1667 'BC' & $1695.25^{\prime} \mathrm{BC}$ ' & 245.94 & $1653 \mathrm{BC}$ \\
\hline $1627 \mathrm{BC}$ & 1641 'BC' & 1668.85 'BC' & 109.5 & $1627 \mathrm{BC}$ \\
\hline- & $1624^{\prime} \mathrm{BC}$ ' & - & - & $1610 \mathrm{BC}$ \\
\hline- & 1599 'BC' & $1623.5^{\prime} \mathrm{BC}$ ' & 178.39 & $1586 \mathrm{BC}$ \\
\hline
\end{tabular}

\section{Absolute dating of Aniakchak}

The Dye3 1645 \pm 20 'BC' acid layer (duplicated in GRIP and NGRIP (North Greenland Ice Core Project) where it is dated to $1641 \pm 5$ ' $\mathrm{BC}$ ') is now known to contain tephra with a chemical profile similar to that of the Aniakchak volcano in Alaska (Pearce et al. 2004; Denton \& Pearce 2008; Coulter et al. 2012). This eruption has been radiocarbon-dated to 1636-1446 cal BC (Blackford et al. 2014). The revised dating in Tables 1 and 2 shows that the Aniakchak II eruption may actually date to $1627 \mathrm{BC}$. This new suggestion illustrates the complexity of the ice-core error. To labour the point, the Dye3 acid layer attributed to Thera does not contain Theran tephra, but it does date to $1627 \mathrm{BC}$.

If, indeed, $1627 \mathrm{BC}$ represents Aniakchak II, rather than the Thera eruption, the original proposition of Baillie and Munro (1988) is also unfounded. The narrowest ring event recorded in the Irish oak chronology merely supported the $1627 \mathrm{BC}$ frost-ring event, suggesting that any climatic effect was at least hemispheric in scale; it could not identify the volcano responsible. Irish oak also shows notably poor growth in the years following $1653 \mathrm{BC}$, culminating in minimum growth in $1650 \mathrm{BC}$ (Figure 1). This again suggests a hemispheric scale of effects by whatever caused the $1653 \mathrm{BC}$ frost ring. Interestingly, this behaviour is similar to the growth response of Irish oaks after $1628 \mathrm{BC}$, which shows minimum growth four years later in $1624 \mathrm{BC}$. This suggests that there is a delayed or sustained deleterious response to the $1653 \mathrm{BC}$ and 1627 BC climatic events. As with the ice error, had the Irish oak response after 1653 BC been known about earlier, this would have caused the Thera debate to develop very differently.

So when did Thera erupt? One extreme possibility is that it occurred within a year or two of $1627 \mathrm{BC}$ and is masked by the Aniakchak II event. Another extreme alternative is that with the revised ice-core dating, the Mediterranean volcano Vesuvius is now known not to have deposited acid or tephra onto Greenland in AD 79/80 (Baillie \& McAneney 2015; Sigl et al. 2015; cf. Barbante et al. 2013); if Vesuvius - although smaller than the Theran eruption-did not register in Greenland ice, is it possible that Thera represents another 'invisible' Mediterranean eruption?

\section{Reviewing evidence for a seventeenth-century BC eruption date for Thera}

In the following discussion, all calibrated dates use IntCal13 and OxCal 4.3.1 (Bronk Ramsey 2009; Reimer et al. 2013), unless otherwise stated. Radiocarbon dating consistently suggests

(C) Antiquity Publications Ltd, 2019 




Figure 1. Revised ice-core dates during the seventeenth century BC for GISP2, and GICC05 ice cores GRIP and NGRIP. Irish oak tree-ring growth is also shown. Note the two-growth minima in the years 1650 and 1624 BC, separated by 26 years matching the interval between the 1653 and 1627 BC frost-ring events in bristlecone pine (grey lines) (figure by J. McAneney).

(C) Antiquity Publications Ltd, 2019 
that Thera erupted in the seventeenth century BC (Manning et al. 2014). When Thera erupted, it destroyed and buried the town of Akrotiri, forming the archaeological stratum known as the Akrotiri volcanic destruction layer (VDL). Samples taken from within the VDL have an average radiocarbon age of $3350 \pm 10 \mathrm{BP}$ (Bronk Ramsey et al. 2004), which calibrates to 1683-1617 cal BC (at 95.4 per cent confidence). Manning et al. (2014) have noted that the weighted mean age of 25 out of 28 short-lived samples recovered from the Akrotiri VDL is $3345 \pm 8 \mathrm{BP}$, with 13 of those specimens measured after $\mathrm{AD} 2000$ having a tight spread of dates with a weighted mean age of $3344 \pm 9 \mathrm{BP}$. These suggest date ranges of $1665-1614 \mathrm{cal}$ BC and 1665-1613 cal BC (at 95.4 per cent confidence), respectively. Various models using Bayesian analysis have been employed on these 25 short-lived samples, further refining the eruption date to $1645-1604 \mathrm{cal} \mathrm{BC}, 1651-1613 \mathrm{cal} \mathrm{BC}$ and 1659-1617 cal BC (all at 95.4 per cent confidence) (Manning 2014: figs RE36A, RE37, RE38, respectively).

A radiocarbon calibration curve is used to convert radiocarbon ages to calendar dates. Due to the non-constant production rate of atmospheric radiocarbon, as well as carbon reservoir effects, the calibration curve exhibits so-called 'wiggles', which can be used to improve the precision of radiocarbon dates. By obtaining a series of radiocarbon ages from samples known to have been deposited or grown over time (such as a series of tree rings), variation of radiocarbon ages through the sample can be matched with the wiggles of the calibration curve. A charred olive branch from Santorini-presumably killed and buried in situ by the Theran eruption fallout-yielded a calendar date range of $1627-1600 \mathrm{cal} \mathrm{BC}$ for its last growth ring, using radiocarbon wiggle-match (IntCal04 and OxCal v4.2, at 95.4 per cent confidence) (Friedrich $e$ et al. 2006); corresponding to 1626-1605 BC (IntCal13 at 95.4 per cent confidence). Vinther et al. (2008) highlighted that, by using IntCal04 wiggle-matching, the dates could be extended to 1654-1597 cal BC (at 95.4 per cent confidence), taking into account the uncertainties associated with counting olive growth rings. This argument was, of course, proposed to preserve the ice-core specialists' belief that the $1641 \pm 5$ 'BC' GICC05 acid belonged to Thera.

Similarly, Cherubini et al. $(2013,2014)$ questioned the validity of the olive branch tree-ring count on the basis that olive trees form irregular annual rings that are often difficult to identify. While Cherubini et al. $(2013,2014)$ advocated a younger date for the Theran eruption, their argument regarding the identification of annual rings remains valid. Indeed, Friedrich et al. (2006, 2014) acknowledged this fact and used X-ray tomography to attempt to identify better the olive tree annual rings. Kuniholm (2014) pointed out that even this may not rectify the problem of obtaining an accurate ring count, as it would still be impossible to resolve the difference between a ring indicating the end of a growing season from a sub-annual growth spurt. Irrespective of these arguments, wiggle-match dating can still be performed if the sample is treated as an ordered (or stratified) sequence of radiocarbon dates (a pseudo-wiggle-match). Such a pseudowiggle-match suggests the last ring of the charred olive branch dates to no later than 1636-1600 cal BC (probably at 91.4 per cent of 95.4 per cent confidence) (Manning et al. 2014).

\section{Relevant evidence for the dating of Thera}

If all radiocarbon evidence strongly suggests that the Theran eruption dates within the seventeenth century $\mathrm{BC}$, then the question remains as to whether our revised ice-core dates can provide a precise date for the eruption. Figure 2 summarises the date ranges from various

(C) Antiquity Publications Ltd, 2019 


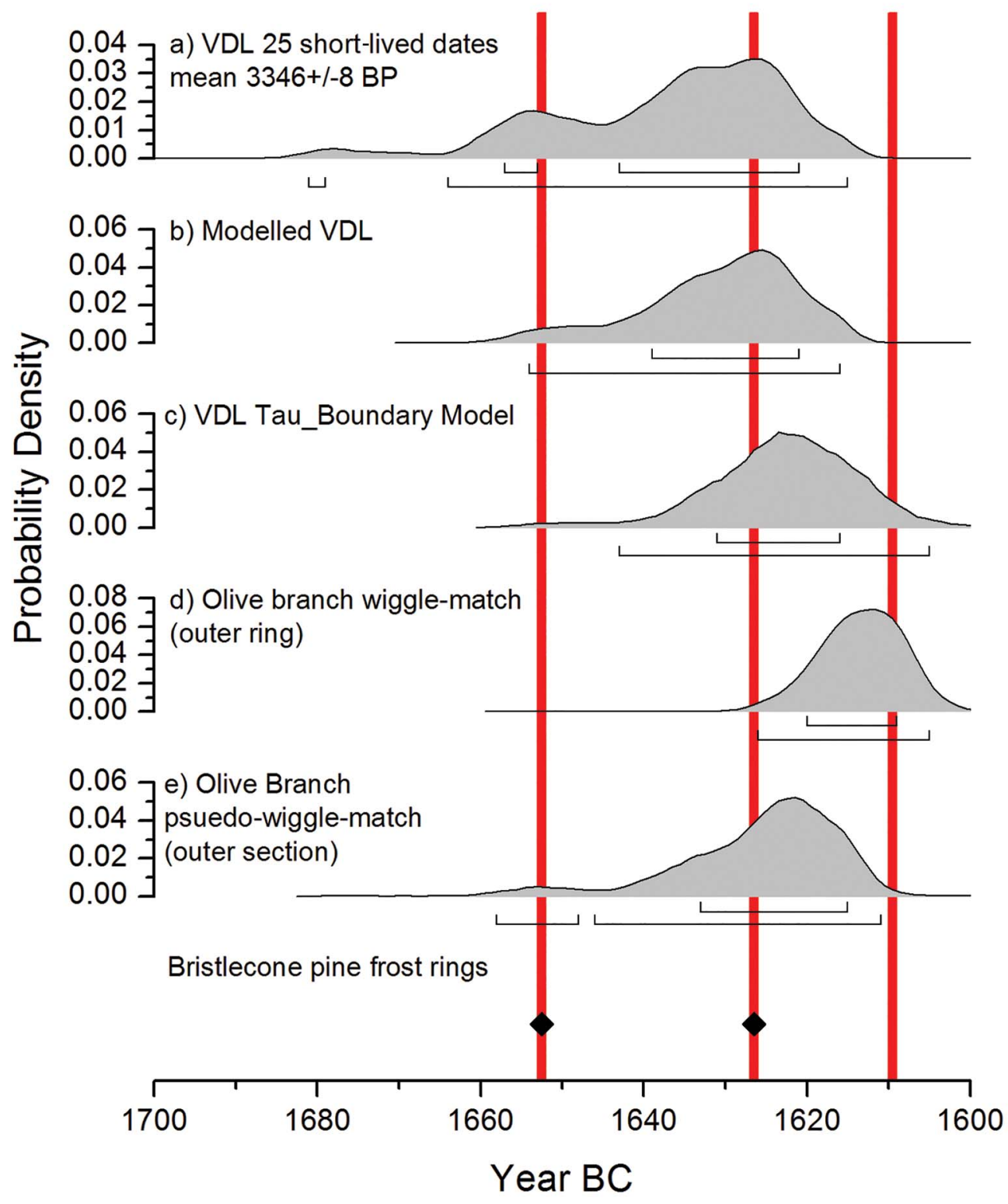

Figure 2. A summary of radiocarbon analyses for the dating of Thera. Curves denote the probability density, and horizontal bars denote the 68.2 per cent and 95.4 per cent probability ranges for various published models (Manning et al. (2006, 2014), Friedrich et al. (2006) and Hölfmayer (2012)). Details of these models can be found in Figures S1-5 in the OSM. Red lines are significant acid signals replicated in at least two of the three ice cores (GISP2, and GICCO5 GRIP and NGRIP) using our revised ice chronology (see Figure 1). Diamonds denote years of bristlecone pine frost-ring events (figure by J. McAneney).

radiocarbon analyses of secure samples directly associated with the volcanic fallout on Santorini-namely, short-lived samples from the VDL at Akrotiri and the buried olive branch (for further details, see the OSM). We include in Figure 2 the volcanic horizons from 
GICC05 and GISP2 ice cores using our revised chronology, plus the bristlecone frost-ring dates. Figure 2 reveals three replicated candidate acid signals in the ice cores at $1653 \mathrm{BC}$, $1627 \mathrm{BC}$ and $1610 \mathrm{BC}$, and one non-replicated NGRIP signal at $1615 \mathrm{BC}$, which could potentially be attributed to Thera. Each date will be examined in turn.

\section{$1653 B C$}

While the $1653 \mathrm{BC}$ acid signal appears to be quite large and climatically effective (as per the coinciding frost ring and reduced growth of Irish oaks), the eruption occurs in the low probability range of most radiocarbon analyses. The best agreement comes from the unmodelled mean date of short-lived samples retrieved from the Akrotiri VDL. Coulter et al. (2012) examined ice layers coeval with the $1653 \mathrm{BC}$ ice acid spike, but did not report finding any tephra that could suggest—or exclude — the $1653 \mathrm{BC}$ volcanic horizon being attributable to Thera. So, while the probability of Thera erupting in $1653 \mathrm{BC}$ is small and unlikely, it cannot currently be eliminated as a possibility.

\section{$1627 B C$}

As outlined above, $1627 \mathrm{BC}$ has been associated with the eruption of Thera since the 1980s. Radiocarbon analyses show that the $1627 \mathrm{BC}$ volcanic horizon is close to the maximum probability for dates obtained from the VDL. When the calibrated radiocarbon dates obtained for the wiggle-matched last growth ring of the buried olive branch are examined, however, the most probable date for the Thera eruption is later than $1627 \mathrm{BC}(1626-1605 \mathrm{cal} \mathrm{BC}$ at 95.4 per cent confidence). We do note that the pseudo-wiggle-match implies a date after 1636 BC (1636-1600 cal BC at 91.3 per cent confidence). Chemical analysis of tephra retrieved from the $1627 \mathrm{BC}$ ice-core acid layer suggests a strong similarity with Aniakchak II, but more significantly, this tephra appears "distinct from any published analyses of tephra from Thera" (Coulter et al. 2012: 6).

Separately, it has been suggested that an anomalous period of invisibility of the planet Venus, recorded in a Babylonian astrological tablet commonly known as the 'Venus Tablet of Ammisaduqa', may be caused by the effects of the eruption of Thera. This interpretation attributes the disappearance of Venus from 9 May 1627 BC (41 days earlier than its calculated conjunction with the Sun) until 19 October of the same year (de Jong \& Foertmeyer 2010) to Thera's atmospheric dust veil. Panagiotakopulu et al. (2013), however, estimated that Thera erupted in early or early mid summer (perhaps June or July) based upon insect activity preserved in storage jars from the West House of Akrotiri (for further discussion, see the OSM). Thus, if the Venus Tablet of Ammisaduqa does preserve a record of a volcanic dust veil in $1627 \mathrm{BC}$, the event may not be associated with Thera. The Venus Tablet thus possibly gives a precise date for the large, caldera-forming eruption of Aniakchak.

\section{$1610 B C$}

The $1610 \mathrm{BC}$ eruption falls outside the most probable range of the VDL dates, suggesting that this was probably not the Theran eruption. Although there is better agreement with the wiggle-matched date for the last olive-branch growth ring, no tephra was recovered (C) Antiquity Publications Ltd, 2019 
from the $1610 \mathrm{BC}$ acid layer, and that from the nearby $1615 \mathrm{BC}$ NGRIP layer "has a low $\mathrm{FeO}$ and high $\mathrm{K}_{2} \mathrm{O}$ composition that is unlike tephra from either Santorini or Aniakchak" (Coulter et al. 2012: 6).

Interestingly, Badertscher et al.'s (2014) trace-element analysis on speleothems from Sofular Cave in north-west Turkey found increased bromine, molybdenum and sulphur deposition dated to $1621 \pm 25 \mathrm{BC}, 1617 \pm 25 \mathrm{BC}$ and $1589 \pm 25 \mathrm{BC}$, which they attributed to the 'down-wind' fallout from Thera. While the date of bromine deposition is marginally younger than the 1653 BC eruption, it does overlap the 1627, 1615 and 1610 BC acid layers. As noted above, however, tephra analysis provides no definitive link between these acid layers and Thera.

\section{Conclusions}

Revision of the current Greenland ice-core chronologies allows us to examine the true volcanic history of the seventeenth century BC with regard to the Bronze Age eruption of Thera. Consideration of the radiocarbon date for the eruption and analysis of volcanic horizons within Greenland ice cores shows that the $1653 \mathrm{BC}$ and $1610 \mathrm{BC}$ eruptions do not agree with both the Akrotiri VDL and olive-branch radiocarbon evidence. Neither eruption therefore is likely to be Thera. While the olive-branch wiggle-match suggests a probable eruption date after $1627 \mathrm{BC}$, the VDL and olive-branch pseudo-wiggle match are compatible with the $1627 \mathrm{BC}$ volcanic horizon in our revised ice-core chronology. Tephra in this volcanic horizon, however, appears to originate from Aniakchak, not Thera. We therefore posit that the large Aniakchak II eruption occurred-in absolute terms-in 1627 or 1628 $\mathrm{BC}$, and we should perhaps now consider excluding the $1627 \mathrm{BC}$ date from the Thera debate. Pedantry does allow for the suggestion that Thera and Aniakchak erupted at points close in time, but, if so, then precise chronologies from trees and ice cores may not be able to resolve them.

Another possibility for the apparent absence of proxy evidence for Thera in the seventeenth century BC is that it erupted later-as interpreted by archaeologists. This, however, requires a degree of flexibility in calibrated radiocarbon dates. Previous iterations of the radiocarbon calibration curve did allow for flexibility in the dating of Thera, with a wider range of errors-particularly with regard to what was included in Bayesian models and the nature of the 'radiocarbon plateau' effect (Bronk Ramsay et al. 2004). Recently, Pearson et al. (2018) published single-year radiocarbon measurements of bristlecone pine and Irish oak. They suggest that radiocarbon ages underpinning the current radiocarbon calibration curves are too young in the sixteenth and seventeenth centuries BC. If confirmed, then calibrated radiocarbon dates for Thera must move forward in time-perhaps as far as the mid sixteenth century $\mathrm{BC}$. This could potentially resolve the 'old' vs 'young' chronology controversy and explain the absence of proxy evidence in our revised seventeenth-century BC ice-core chronology.

A robust way to test our revised ice-core chronologies would be to find direct linkages between the ice-core chronology and tree-ring chronologies using so-called 'Miyake events' (Miyake et al. 2012, 2013). These are events marked by sudden radiocarbon and beryllium 10 enrichment over the period of a year, as demonstrated in $\mathrm{AD} 775$ and 994 (Sigl et al. 2015). As noted earlier, Adolphi and Muscheler (2016), using a similar radiocarbon-

(C) Antiquity Publications Ltd, 2019 
beryllium 10 linkage but at lower resolution, proposed that the GICC05 ice chronology for the seventeenth century BC was too old by $20 \pm 5$ years. Dee and Pope (2016) have suggested a possible Miyake event in $1677 \mathrm{BC}$, which, if correct, could be exploited in both ice-core and tree-ring research relevant to the Thera debate (an optimistic hope being a measurable signature of excess radiocarbon in one of the 72 rings of the Theran olive branch). A Miyake event in $1677 \mathrm{BC}$ may also permit the absolute dating of the Anatolian tree-ring chronology_-in particular the Porsuk and Gordion site chronologies—and thus give a precise calendar date for the Porsuk growth anomaly.

\section{Acknowledgements}

We wish to thank Sturt Manning and an anonymous referee for constructive comments that have helped to improve this paper.

\section{Supplementary material}

To view supplementary material for this article, please visit https://oi.org/10.15184/aqy. 2018.165

\section{References}

Adolphi, F. \& R. Muscheler. 2016. Synchronising the Greenland ice core and radiocarbon timescales over the Holocene-Bayesian wiggle-matching of cosmogenic radionuclide records. Climate of the Past 12: 15-30. https://doi.org/10.5194/cp-12-15-2016

Badertscher, S., A. Borsato, S. Frisia, H. Cheng, R.L. Edwards, O. Tuysuz \& D. Fleitmann. 2014. Speleothems as sensitive recorders of volcanic eruptions - the Bronze Age Minoan eruption recorded in a stalagmite from Turkey. Earth and Planetary Science Letters 392: 58-66. https://doi.org/10.1016/j.epsl.2014.01.041

Baillie, M.G.L. 2008. Proposed re-dating of the European ice core chronology by seven years prior to the $7^{\text {th }}$ century AD. Geophysical Research Letters 35(15): L15813.

-2010 . Volcanoes, ice-cores and tree-rings: one story or two? Antiquity 84: 202-15. https://doi.org/10.1017/S0003598X00099877

Baillie, M.G.L. \& J. McAneney. 2015. Tree ring effects and ice cores clarify the volcanic record of the first millennium AD. Climate of the Past 11: 105-14. https://doi.org/10.5194/cp-11-105-2015

Baillie, M.G.L. \& M.A.R. Munro. 1988. Irish tree rings, Santorini and volcanic dust veils. Nature 332: 344-46. https://doi.org/10.1038/332344a0

(C) Antiquity Publications Ltd, 2019
Barbante, C., N.M. Kehrwald, P. Marianelli, B.M. Vinther, J.P. Steffensen, G. Cozzi, C.U. Hammer, H.B. Clausen \& M.L. SiggaArd-Andersen. 2013. Greenland ice core evidence of the $79 \mathrm{AD}$ Vesuvius eruption. Climate of the Past 9: 1221-32. https://doi.org/10.5194/cp-9-1221-2013

BIETAK, M. 2003. Science versus archaeology: problems and consequences of high Aegean chronology, in M. Bietak (ed.) The synchronisation of civilisations in the Eastern Mediterranean in the second millennium BC. II: 23-33. Vienna: Austrian Academy of Sciences.

- 2014. Radiocarbon and the date of the Thera eruption. Antiquity 88: 277-82. https://doi.org/10.1017/S0003598X00050389

Blackford, J.J., R.J. Payne, M.P. Heggen, A. De la Riva Caballero \& J. van der Plicht. 2014. Age and impacts of the caldera-forming Aniakchak II eruption in western Alaska. Quaternary Research 82: 85-95. https://doi.org/10.1016/j.yqres.2014.04.013

Bronk Ramsey, C. 2009. Bayesian analysis of radiocarbon dates. Radiocarbon 51: 337-60. https://doi.org/10.1017/S0033822200033865

Bronk Ramsey, C., S.W. Manning \& M. Galimberti. 2004. Dating the volcanic eruption at Thera. Radiocarbon 46: 325-44. https://doi.org/10.1017/S0033822200039631

Cherubini, P., T. Humbel, H. Beeckman, H. Gärtner, D. Mannes, C. Pearson, 
W. Sсносн, R. Tognetti \& S. Lev-Yadun. 2013. Olive tree-ring problematic dating: a comparative analysis on Santorini (Greece). PLoS ONE 8(1): e54730.

https://doi.org/10.1371/journal.pone.0054730

- 2014. The olive-branch dating of the Santorini eruption. Antiquity 88: 267-73. https://doi.org/10.1017/S0003598X00050365

Clausen, H.B., C.U. Hammer, C.S. Hvidberg, D. Dahl-Jensen, J.P. Steffensen, J. Kipfstuhl \& M. Legrand. 1997. A comparison of the volcanic records over the past 4000 years from the Greenland Ice Core Project and Dye 3 Greenland ice cores. Journal of Geophysical Research 102 (C12): 26707-23. https://doi.org/10.1029/97JC00587

Coulter, S.E., J.R. Pilcher, G. Plunkett, M.G.L. Baillie, V.A. Hall, J.P. Steffensen, B.M. Vinther, H.B. Clausen \& S.J. Johnsen. 2012. Holocene tephras highlight complexity of volcanic signals in Greenland ice cores. Journal of Geophysical Research 117(D21): D21303. https://doi.org/10.1029/2012JD017698

Dee, M.W. \& B.J.S. Pope. 2016. Anchoring historical sequences using a new source of astro-chronological tie-points. Proceedings of the Royal Society A 472: 20160263.

https://doi.org/10.1098/rspa.2016.0263

De Jong, T. \& V. Foertmeyer. 2010. A new look at the Venus observations of Ammisaduqa: traces of the Santorini eruption in the atmosphere of Babylon? Jaarbericht van het Vooraziatisch-Egyptisch Genootschap 'Ex Oriente Lux' 42: 143-59.

Denton, J.S. \& N.J.G. Pearce. 2008. Comment on 'A synchronised dating of three Greenland ice cores throughout the Holocene' by B.M. Vinther et al.: no Minoan tephra in the 1642 B.C. layer of the GRIP ice core. Journal of Geophysical Research 113: D04303.

https://doi.org/10.1029/2007JD008970

Friedrich, W.L., B. Kromer, M. Friedrich, J. Heinemeier, T. Pfeiffer \& S. Talamo. 2006. Santorini eruption radiocarbon dated to $1627-$ 1600 B.C. Science 312: 548.

https://doi.org/10.1126/science.1125087

- 2014. The olive branch chronology stands irrespective of tree-ring counting. Antiquity 88: 274-77.

https://doi.org/10.1017/S0003598X00050377

Hammer, C.U., H.B. Clausen, W.L. Friedrich \& H. Tauber. 1987. The Minoan eruption of Santorini in Greece dated to 1645 BC? Nature 328: 517-19.

https://doi.org/10.1038/328517a0

HöflmaYer, F. 2012. The date of the Minoan Santorini eruption: quantifying the 'offset'. Radiocarbon 54: 435-48. https://doi.org/10.1017/S0033822200047196

Kuniholm, P.I. 2014. The difficulties of dating olive wood. Antiquity 88: 287-88. https://doi.org/10.1017/S0003598X00050407

LaMarche, V.C. \& K.K. Hirschboeck. 1984. Frost rings in trees as records of major volcanic eruptions. Nature 307: 121-26. https://doi.org/10.1038/307121a0

Manning, S.W. 2014. A test of time and a test of time revisited. The volcano of Thera and the chronology and history of the Aegean and East Mediterranean in the mid-second millennium $B C$. Oxford: Oxbow.

Manning, S.W., B. Kromer, P.I. Kuniholm \& M.W. Newton. 2001. Anatolian tree rings and a new chronology for the East Mediterranean Bronze-Iron Ages. Science 294: 2494-95. https://doi.org/10.1126/science.1066112

Manning, S.W., C. Bronk Ramsey, W. Kutschera, T. Higham, B. Kromer, P. Steier \& E.M. Wild. 2006. Chronology for the Aegean Late Bronze Age 1700-1400 BC. Science 312: 565-69. https://doi.org/10.1126/science.1125682

Manning, S.W., F. Höflmayer, N. Moeller, M.W. Dee, C. Bronk Ramsey, D. Fleitmann, T. Higham, W. Kutschera \& E.M. Wild. 2014. Dating the Thera (Santorini) eruption: archaeological and scientific evidence supporting a high chronology. Antiquity 88: 1164-79. https://doi.org/10.1017/S0003598X00115388

Manning, S.W., C.B. Griggs, B. Lorentzen, G. Barjamovic, C. Bronk Ramsey, B. Kromer \& E.M. WiLD. 2016. Integrated tree-ring-radiocarbon high-resolution timeframe to resolve earlier second millennium BCE Mesopotamian chronology. PLoS ONE 11: e0157144.

https://doi.org/10.1371/journal.pone.0157144

Miyake, F., K. Nagaya, K. Masuda \& T. NAKAMURA. 2012. A signature of cosmic-ray increase in $\mathrm{AD} 774-775$ from tree rings in Japan. Nature 486: 240-42.

https://doi.org/10.1038/nature11123 
Miyake, F., K. Masuda \& T. Nakamura. 2013. Another rapid event in the carbon-14 content of tree rings. Nature Communications 4: 1748. https://doi.org/10.1038/ncomms2783

Panagiotakopulu, E., T. Higham, A. Sarpaki, P. Buckland \& C. Doumas. 2013. Ancient pests: the season of the Santorini Minoan volcanic eruption and a date from insect chitin. Naturwissenschaften 100: 683-89. https://doi.org/10.1007/s00114-013-1068-8

Pearce, N.J.G., J.A. Westgate, S.J. Preece, W.J. Eastwood \& W.T. Perkins. 2004. Identification of Aniackchak (Alaska) tephra in Greenland ice core challenges the 1645 BC date for the Minoan eruption of Santorini. Geochemistry Geophysics Geosystems 5: Q03005. https://doi.org/10.1029/2003GC000672

Pearson, C.L., D.S. Dale, P.W. Brewer, P.I. Kuniholm, J. Lipton \& S.W. Manning. 2009. Dendrochemical analysis of a tree-ring growth anomaly associated with the Late Bronze Age eruption of Thera. Journal of Archaeological Science 36: 1206-14. https://doi.org/10.1016/j.jas.2009.01.009

Pearson, C.L., P.W. Brewer, D. Brown, T.J. Heaton, G.W.L. Hodgins, A.J.T. Jull, T. Lange \& M.W. Salzer. 2018. Annual radiocarbon record indicates $16^{\text {th }}$ century BCE date for the Thera eruption. Science Advances 4: eaar8241. https://doi/10.1126/sciadv.aar8241

Reimer, P.J. et al. 2013. IntCal13 and Marine13 radiocarbon age calibration curves $0-50,000$ years cal BP. Radiocarbon 55: 1869-87. https://doi.org/10.2458/azu_js_rc.55.16947

SAlzer, M.W. \& M.K. Hughes. 2007.

Bristlecone pine tree rings and volcanic eruptions over the last 5000 yr. Quaternary Research 67: 57-68. https://doi.org/10.1016/j.yqres.2006.07.004

Seierstad, I.K. et al. 2014. Consistently dated records from the Greenland GRIP, GISP2 and
NGRIP ice cores for the past 104 ka reveal regional millennial-scale $\mathrm{d} 18 \mathrm{O}$ gradients with possible Heinrich event imprint. Quaternary Science Reviews 106: 29-46. https://doi.org/10.1016/j.quascirev.2014.10.032

SIGL, M. et al. 2015. Timing and climate forcing of volcanic eruptions for the past 2,500 years. Nature 523: 543-49. https://doi.org/10.1038/nature14565

Southon, J. 2002. A first step to reconciling the GRIP and GISP2 ice-core chronologies, $0-14,500$ yr B.P. Quaternary Research 57: 32-37. https://doi.org/10.1006/qres.2001.2295

Vinther, B.M., H.B. Clausen, S.J. Johnsen, S.O. Rasmussen, K.K. Andersen, S.L. Buchardt, D. Dahl-Jensen, I.K. Seierstad, M.L. Siggaard-Andersen, J.P. Steffensen, A. Svensson, J. Olsen \& J. Heinemeier. 2006. A synchronized dating of three Greenland ice cores throughout the Holocene. Journal of Geophysical Research 111: D13102. https://doi.org/10.1029/2005JD006921

Vinther, B.M, H.B. Clausen, S.J. Johnsen, S.O. Rasmussen, J.P. Steffensen, K.K. Andersen, S.L. Buchardt, D. Dahl-Jensen, I.K. Seierstad, A. Svensson, M.L. Siggaard-Andersen, J. Olsen \& J. Heinemeier. 2008. Reply to comment by J.S. Denton and N.J.G. Pearce on 'A synchronized dating of three Greenland ice cores throughout the Holocene'. Journal of Geophysical Research 113: D12306. https://doi.org/10.1029/2007JD009083

Zielinski, G.A., P.A. MaYewsKi, L.D. Meeker, S. WhitLow, M.S. TwickLer, M. Morrison \& D.A. MeEse. 1994. Record of volcanism since 7000 B.C. from the GISP2 Greenland ice core and implications for the volcano-climate system. Science 264: 948-52. https://doi.org/10.1126/science.264.5161.948

Received: 6 February 2018; Revised: 18 May 2018; Accepted: 5 June 2018

(C) Antiquity Publications Ltd, 2019 